Humphreys, Ltd., of Knightsbridge, generously undertook the responsibility, and a number of other firms collaborated in the construction and equipment. The model is to a scale of one sixteenth of full size, and includes adults' and children's wards, complete with bathrooms, lavatories and sink rooms, and with circular solarium at the end, operating theatres, X-ray apparatus, staircases and working electric lift, board room and kitchen, balconies and garden, together with figures of doctors, nurses and patients. The work was executed by a staff of skilled craftsmen, and so far as possible every detail essential to a building of this kind has been reproduced in the model-furniture, bedding, screens, radiators and others too numerous to mention. The model is on view until further notice at British Industries House, Hereford House, Oxford Street, London.

\section{Agricultural and Horticultural Research}

THE year 1934, coming after a period of monetary anxiety, brought financial stability to the National Fruit and Cider Institute and Research Station at Long Ashton, Bristol. This gratifying state of affairs has allowed the completion, or further prosecution, of several important pieces of investigational work. Some results of these are published in the annual report of the Station for 1934 (Long Ashton, pp. 312, July 1935). A foreword by Prof. B. T. P. Barker, the director, outlines the administrative changes of the organisation, and also of the Berkeley Square Advisory Centre, Bristol. The principal contributions of research results are three papers on the maturity of fruit by Dr. J. C. Hinton (NATURE, Oct. 26, p. 687), whilst numerous studies of pests and plant pathology have been prosecuted. The cider investigations include a consideration of the suitability of various containers for apple juice, the role of pectin in cidermaking, experiments on clarification of the juice, and preservation with sulphur dioxide. A soil survey of the Teart Land areas of Somerset is also being made.

\section{Television in Australia}

Baird Television, Lto. announces that as the result of negotiations with the Australian Radio Manufacturers' Patents Association, Ltd., of Sydney, the Association has been appointed the exclusive representatives in Australia of the Baird Company, both for the construction and operation of television transmitting stations and the manufacture of television receivers under the Baird patents. The Australian Radio Manufacturers' Patents Association, Ltd. is composed of a majority of the leading radio manufacturers throughout the Commonwealth of Australia, and they propose to develop television as an adjunct to sound broadcasting. Experimental transmitters will, it is expected, be erected in Sydney and Melbourne in the near future, with the view of providing ultimately a commercial high-definition television service.

\section{Louis Lumière Celebrations}

A Meeting to celebrate the fortieth anniversary of the invention of the cinematographe by Louis and
Auguste Lumiere will be held in the Hall of the Sorbonne, Paris, on November 6 at 9 p.m. The meeting will be held under the presidency of M. Mario Roustan, Minister of Education; and M. Albert Lebrun, President of the Republic, will be present. Among the discourses will be one given by Prof. C. Fabry, professor of physics in the Sorbonne and president of the French Society of Photography and Cinematography. During the celebrations, certain films made in 1894, and colour photographs of 19071935, will be exhibited. Further information can be obtained from the Secrétaire Général, 11 Avenue Casimir, Asnières (Seine).

\section{Awards of the Institution of Civil Engineers}

THe following awards of the Institution of Civil Engineers have recently been made for papers read and discussed at ordinary meetings : a Telford Gold Medal to B. M. Hellstrom (London); a Telford Premium jointly to F. W. D. Davis (London) and William Mackenzie (Hull); a Telford Premium to G. L. Groves (London) ; a Telford Premium jointly to C. Seager Berry (Baldock) and A. C. Dean (Manchester); a Telford Premium to E. J. Buckton (London); a Telford Premium to W. J. H. Rennie (Singapore); a Telford Premium and the Coopers Hill War Memorial Prize to A. W. H. Dean (New Delhi); a Telford Premium and the Indian Premium to M. G. Platts (Madras) ; a Telford Premium jointly to J. A. K. Hamilton (Cleveland, York) and J. Tudor Graves (Middlesbrough); a Telford Premium to Alexander Gray (St. John, Canada) ; a Trevithick Premium to George Mclldowie (Newcastle, Co. Down); a Trevithick Premium jointly to W. T. W. Miller (Sheffield) and R. J. Sargant (Sheffield); a Manby Premium to M. A. Ravenor (London); a Crampton Prize jointly to V. F. Bartlett (London) and W. H. Cadwell (Mellor, Derbyshire). For papers published without discussion as 'Selected Engineering Papers' : a Telford Premium to T. H. Hopkins (Bromley, Kent); a Telford Premium jointly to Prof. E. G. Coker (London) and G. P. Coleman (London); a Telford Premium to Ralph Poole (Bradbury, Cheshire); a Telford Premium to W. H. Weston (Glasgow); a Telford Premium to C. G. Watson (London). For papers read at students' meetings: the James Forrest Medal and a Miller Prize to James Halliday (Dunbar); Miller Prizes to R. S. Cogdon (Sunderland), Geoffrey Wood (London), R. G. Rowbotham (Buenos Aires), G. R. Coles (St. Albans, Herts) and J. L. Matheson (Stafford). The Charles Hawksley Prize has been awarded to Frank W. Curry (London).

\section{Announcements}

AT the annual statutory meeting of the Royal Society of Edinburgh held on October 28 the following council was elected: President: Prof. D'Arcy Wentworth Thompson; Vice-Presidents : Prof. C. G. Darwin, Prof. R. A. Sampson, Principal O. Charnock Bradley, Prof. P. T. Herring, the Marquis of Linlithgow and Prof. E. B. Bailey; General Secretary : Prof. J. H. Ashworth; Secretaries to Ordinary 